\section{Pathophysiology of Haemostasis and Thrombosis}

\title{
Metalloproteinases in Development and Progression of Vascular Disease
}

\author{
H. Roger Lijnen
}

Center for Molecular and Vascular Biology, KU Leuven, Belgium

Key Words

Restenosis · Neointima - Atherosclerosis - Aneurysm . Metalloproteinase

\begin{abstract}
Remodeling of the vascular wall plays a role in many physiological processes, but also in the pathogenesis of major cardiovascular diseases such as restenosis and atherosclerosis. Remodeling requires proteolytic activity to degrade components of the extracellular matrix; this can be generated by the matrix metalloproteinase (MMP) system alone or in concert with the fibrinolytic (plasminogen/plasmin) system. Several lines of evidence suggest that the MMP system plays a role in vascular smooth muscle cell migration and neointima formation after vascular injury. In atherosclerotic lesions, active MMPs may contribute to plaque destabilisation by degrading extracellular matrix components, but may also promote aneurysm formation by proteolytic degradation of the elastic lamina. The MMP system may therefore represent a potential therapeutic target for treatment of restenosis or atherosclerosis.
\end{abstract}

Copyright (c) 2004 S. Karger AG, Base

\section{KARGER}

Fax +4161306 1234 E-Mail: karger@karger.ch www.karger.com
(C) 2004 S. Karger AG, Basel 1424-8832/04/0336-0275\$21.0/0

Accessible online at: www.krager.com/pht

\section{Introduction}

Remodeling of the vascular wall in response to changes in its hemodynamic environment may occur through a variety of structural adaptations, that may result in vessel enlargement or diminution. The direction and extent of vascular remodeling is coordinated via endothelial production of growth factors, cellular adhesion molecules and proteinases [1]. Inappropriate remodeling underlies the pathogenesis of major cardiovascular dieseases such as restenosis and atherosclerosis. Cell migration and tissue remodeling require degradation of extracellular matrix (ECM). Two proteolytic systems, the fibrinolytic (plasminogen/plasmin) and matrix metalloproteinase (MMP) systems in concert can degrade most ECM components. Plasmin can only degrade some components of the ECM directly, such as laminin and fibronectin, whereas other components such as elastin and collagen are degraded by MMPs. The plasminogen/plasmin system can, however, play a role in the activation of several proMMPs. The role of both systems in vascular remodeling and atherogenesis has recently been reviewed [2,3].

Vascular remodeling does not only play a role in disease states; it also contributes to physiological processes such as blood vessel growth and regression during fetal development and growth, exercise training and pregnancy [4]. In this contribution we will focus on the potential role of the MMP system in arterial restenosis and atherosclerosis.

\section{H. Roger Lijnen}

Center for Molecular and Vascular Biology

KU Leuven, Campus Gasthuisberg, O \& N

Herestraat 49, B-3000 Leuven, Belgium

Tel: +32 16 345771; Fax: +32 16 345990; E-mail: roger.lijnen@med.kuleuven.ac.be 
Vascular interventions for the treatment of atherothrombosis induce restenosis of the vessel within 3-6 months in 30-50\% of treated patients. Arterial stenosis may result from remodeling of the vessel wall (such as occurs predominantly after balloon angioplasty) and/or from accumulation of cells and ECM in the intimal layer (such as occurs predominantly after intraluminal stent application).

Atherosclerotic lesions initially consist of fatty streaks that develop into fibroproliferative lesions. A mature lesion consists mainly of foam cells, smooth muscle cells (SMC), a necrotic core and a fibrous cap containing extracellular matrix components. Clinical complications of atherosclerosis are often triggered by rupture of unstable plaques, whereas thinning of the atherosclerotic vessel wall due to elastin and collagen degradation and media necrosis may result in aneurysm formation and bleeding. Proteolysis may contribute to neovascularization and rupture of plaques, or to ulceration and rupture of aneurysms.

\section{MMP Family}

MMPs constitute a tightly regulated family of zinc dependent endopeptidases that degrade most components of the ECM and basement membrane, and can also function in many other proteolytic processes. Most MMPs are synthesized and secreted as inactive proenzymes. MMPs comprise several domains. The signal peptide (17-29 amino acids) is followed by the propeptide domain (77-87 amino acids) that constitutes the amino-terminus of the enzyme. It contains a unique conserved sequence with a cysteine residu that ligates the catalytic zinc to maintain the latency of the proenzymes. MMP-23 lacks this sequence but contains a conserved cysteine, while some others, e.g. MMP-11, MMP-14, MMP-15, MMP-16 and MMP-17 have a furin recognition site, and Xenopus MMP has an additional vitronectin-like domain [5,6]. The catalytic domain (about 170 amino acids) contains the catalytic machinery including the zinc-binding site and a conserved methionine [7]. This domain contains additional zinc and calcium ions which maintain the three dimensional structure of MMPs, required for their stability and enzymatic activity. The two gelatinases (MMP-2 and MMP-9) contain additional repeats of fibronectin-like domains which interact with collagen and gelatins. The carboxy-terminal hemopexin-like domain (about 210 amino acids) has an ellipsoidal disc shape and plays a key role in substrate specificity [8]. The hemopexin domain of proMMP-2 is also required for its cell surface activation by MT1-MMP [9]. MMP-7 and MMP-26 lack this domain entirely and in some members of the MMP family, e.g., MMP-23, the hemopexin domain is substituted by a cysteine-rich, proline-rich and interleukin-1 receptor-like motif.
The catalytic and the hemopexin domains are linked by a proline-rich linker domain (the hinge region). A transmembrane domain occurs in MT-MMPs, which anchors them to he cell surface [10].

The members of the MMP family (23 identified at present) are divided into five classes based on their structure and substrate specificities. These are collagenases, gelatinases, stromelysins, membrane type MMPs (MT-MMPs) and others. Although each MMP is encoded by a different gene, there is a high degree of sequence homology and structural domain conservation. MMPs are synthesized, and mostly also secreted as zymogens that are extracellularly activated by several proteinases (including plasmin, trypsin, chymotrypsin, kallikrein, cathepsin, or neutrophil elastase and other MMPs) or in vitro by non-proteolytic agents such as 4-aminophenyl mercuric acetate, hypochlorous acid, oxidized glutathione, and denaturants [11].

Active MMPs are inhibited by tissue inhibitors (TIMPs); four homologous TIMPs (TIMP-1 to -4) have been identified. They form noncovalent complexes with the active forms of MMPs as well as with some proMMPs, thereby inhibiting active MMPs or impairing the activation of proMMPs [12].

\section{Arterial Restenosis}

\section{Expression of MMP Components}

Proteinases from the MMP system participate in the proliferation and migration of SMC, and in matrix remodeling during arterial wound healing [3,13-17]. Only MMP-2 appears to be expressed in the quiescent SMC, whereas expression of MMP-3, -7, -9, -12 and -13 is induced in injured, transplanted, or atherosclerotic arteries [18-23]. In a balloon-injured rat carotid artery model, a correlation was observed between changes in MMPs and SMC migration $[24,25]$. Increased levels of TIMP-2 in this model suggested that changes in the proteolytic balance play a role in SMC migration after arterial injury [26].

Furthermore, it was demonstrated that SCM migration in baboon aortic explants requires plasminogen activators, MMP-2, MMP-9, basic fibroblast growth factor (bFGF) and platelet-derived growth factor (PDGF) [27,28]. PDGFinduced migration of SMC depended on MMP-2, whereas bFGF-induced migration depended on both MMP-2 and MMP-9 [28]. Studies in balloon-injured rabbit carotid arteries suggested that MMP-2 facilitates migration of SMC from the media to the intima and does not affect replication [29]. In patients with ischemic heart disease coronary angioplasty induces MMP-2 activity in the coronary circulation, which may contribute to vascular remodeling and late restenosis [30]. Serum MMP-9 levels are also elevated in 
patients with severe coronary stenosis [31] and may constitute a predictor of cardiovasular mortality in patients with coronary artery disease. At present, the association between polymorphisms in MMP genes (MMP-2, -3, -9 and -12) and cardiovascular disease is also under investigation [32,33].

To assess the role of the MMP system in SMC migration and neointima formation experimentally, a perivascular electric injury model in the mouse has been used [34]. In this model, surgically exposed femoral arteries are injured perivascularly via delivery of an electric current, which destroys all medial SMC, denudes the injured segment of intact endothelium, and transiently induces platelet-rich mural thrombosis. A vascular wound healing response results characterized by repopulation of the media and accumulation in the neointima of SMC originating from the uninjured borders.

The temporal and topographic expression pattern of MMPs (MMP-2, -3, -9, -12 and -13) after vascular injury in this model is compatible with a role in ECM degradation and SMC migration [35]. Two weeks after injury, MMP-2 and -3 are detected in $\alpha$-actin stained SMC. MMP-9, -12 and -13 are found in macrophages located mainly in the adventitia and only occasionally in subintimal areas. Total MMP-9 levels (active plus latent) are also markedly increases after injury. MMP-3 expression after injury gradually increases to reach a maximum at about 2 weeks. These data are compatible with findings in the rat carotid artery model, showing constitutive expression of latent MMP-2 and markedly enhanced levels of active MMP-2 up to 7 days after balloon injury, whereas also active and latent MMP-9 are induced after injury [24,36]. In this rat model, MMP-3 is detectable as early as 2 hours after balloon injury and reaches a maximal 2-fold increase at 7 days [36].

\section{Studies in Gene-Deficient Mice}

A role of MMP-9 in arterial remodeling by promoting migration and replication of SMC is confirmed by injury models in MMP-9 deficient mice [37,38]. Deficiency of MMP-2 in mice suppresses SMC invasion and development of experimental intimal hyperplasia [39]. Mice with MMP11 (stromelysin-3) deficiency show accelerated neointima formation after vascular injury [40]. Intima/media ratio's are significantly enhanced in MMP-11-/- mice as a result of enhanced neointima formation 2 to 3 weeks after injury.

In mice with deficiency of TIMP 1 , the intimal areas at 1 to 3 weeks after injury are significantly larger than in wildtype mice, and contain abundant SMC, whereas the medial areas are comparable, resulting in significantly higher intima/media ratio's in the TIMP-1 deficient mice. These data thus support a physiological role of TIMP-1 in vascular remodeling, most likely via monitoring of MMP activity. This is further supported by the finding that stromelysin

Metalloproteinases in Vascular Disease
mRNA antisense oligonucleotides inhibit phenotypic modulation of rat arterial SMC and thereby cause a decrease in migration and proliferation and in neointima formation after vessel wall injury [42].

\section{Pharmacological Modulation of MMP Activity}

Non-specific MMP inhibitors have been studied in several animal models in vivo and ex vivo. Marimastat inhibits gelatinase activity and reduces neointimal thickening in cultured human internal mammary arteries, a model of arterial intimal hyperplasia [43]. Metalloproteinase inhibition by Batimastat reduces late lumen loss after balloon angioplasty in atherosclerotic micropigs by inhibition of constrictive arterial remodeling, without effect on neointima formation [44]. MMP inhibition by GM6001 blocks in-stent intimal hyperplasia in a rabbit model [45]. In vivo SMC migration in the rat is also inhibited by administration of MMP inhibitors [24,46].

Alternative approaches include overexpression of TIMP-1 [47]. Adenoviral gene transfer of TIMP-1 reduces neointimal hyperplasia in balloon-injured rat carotid arteries [48] and intimal thickening in a rabbit restenosis model [49]. Adenovirus-mediated gene transfer of the human TIMP-1 gene inhibits SMC migration and neointimal formation in the human saphenous vein [50]. A hybrid protein consisting of TIMP-1 linked to the receptor-binding amino-terminal fragment of u-PA strongly enhances the inhibitory effect of TIMP-1 on neointima formation, presumably by blocking binding of u-PA to u-PAR and imparing cellular plasminogen activation [51].

Taken together, these data are compatible with a role of MMPs in ECM degradation and SMC migration after vascular injury.

\section{Atherosclerosis}

\section{Expression of MMP System Components}

A potential role for increased proteolysis in atherosclerosis is supported by the enhanced expression of t-PA, u-PA and several MMPs in plaques [19,22,52,53]. Several MMP system components (MMP-1, -2, -3 and -9) are expressed in atherosclerotic tissue [20,54,55]; in their active form they may contribute to vascular remodeling and plaque disruption. Stromelysin-3 (MMP-11), an unusual MMP that does not degrade any of the major ECM components, is also expressed in human atherosclerotic lesions and is regulated via CD40-CD40 ligand signaling [56]. Expression of MT1MMP in human atherosclerotic plaques is upregulated by proinflammatory mediators [57]. Coexpression of cyclooxygenase-2 with MMP-9 and MT1-MMP by macrophages and SMC in atherosclerotic lesions was reported [58]. SMCs

Pathophysiol Haemost Thromb 2003/2004;33:275-281 
and macrophages in human atherosclerotic plaques also express MT3-MMP; its increased expression by macrophages induced by inflammatory molecules may promote ECM degradation and contribute to plaque destabilization [59]. Expression of MMP-9 is upregulated and that of TIMP-1 downregulated in human monocyte-derived macrophages by oxidized low-density lipoprotein, suggesting that these may contribute to matrix degradation in the atherosclerotic plaque, predisposing to plaque rupture and/or vascular remodeling [60]. Also interleukin-8 downregulates TIMP-1 expression in cholesterol-loaded human macrophages and may affect the stability of atherosclerotic plaques and thus play a potential atherogenic role [61]. Regulated expression of TIMP-3, in addition to TIMP-1 and TIMP-2, was shown to counteract MMP activity in atheroma and hence to influence plaque stability [62].

Differences in expression of MMPs/TIMPs may determine the evolution of advanced atherosclerotic plaques and contribute to their vulnerability. Thus, MMP-1 and -3 are more expressed in human aneurysm lesions than in occlusive plaques, whereas MMP-9 is mainly detected in carotid as compared with femoral arteries, and TIMP-1 was associated with arterial calcification [63]. Leukocyte-derived MMP-9 is associated with aortic wall degeneration and aneurysm formation [64]. Serum levels of MMP-3 and -9 and of TIMP-1 are elevated in asymptomatic hyperlipidemic subjects at high cardiovascular risk, and MMP-3 and TIMP-1 levels are strongly positively associated with the presence of carotid lesions [65]. Measurement of serum MMP-9 levels may represent a novel marker of inflammation in patients with coronary artery disease and might provide an index of plaque activity [66].

It should also be kept in mind that several members of other classes of proteases are expressed and regulated in atherosclerotic lesions (e.g. serine, cysteine and aspartic proteases) and may contribute to ECM remodeling $[67,68]$.

\section{Studies in Gene-deficient Mice}

In the atherosclerosis suscpetible ApoE-/- mice, expression of MMPs in atherosclerotic lesions depends on the size of the lesion but also on the genetic background. Thus, C3H/HeJ Apo E-deficient mice show increased MMP-2 and -12 activity in aortas and macrophages compared with those of C57Bl/6 ApoE-/- mice. MMP-9 activity is comparable in aortic tissues of the 2 strains but is higher in macrophages from C3H/HeJ ApoE-/- mice [69].

The hypothesis that MMP-3 may play a role in development and progression of atherosclerotic lesions and in aneurysm formation, was tested with the use of mice with deficiency of ApoE (ApoE-/-:MMP-3+/+) or with combined deficiency of ApoE and MMP-3 (ApoE-/-:MMP-3-/-), kept on a cholesterol-rich diet [70]. Atherosclerotic lesions throughout the thoracic aorta are significantly larger in ApoE-/-:MMP-3-/- than in ApoE-/-:MMP-3+/+ mice, and contain more fibrillar collagen. Aneurysms in the thoracic and abdominal aorta are less frequent in ApoE-/-:MMP-3-/than in ApoE-/-:MMP-3+/+ mice. Immunocytochemistry reveals significantly enhanced accumulation of macrophages in atherosclerotic lesions of ApoE-/:MMP$3+/+$ mice and expression of urokinase-type plasminogen activator (u-PA) and MMP-3, colocalizing with macrophages. Zymography confirms the presence of u-PA and MMP-3 activity in extracts of atherosclerotic aorta's. These data suggest that plasmin, generated via macrophagesecreted u-PA activates proMMP-3 produced by accumulated macrophages. MMP-3 may thus on the one hand contribute to plaque destabilization, possibly by degrading extracellular matrix components, and on the other hand promote aneurysm formation by degrading the elastic lamina. Using the same model, it was recently shown that ApoE-/:MMP-9-/- plaques are smaller and contain fewer macrophages than ApoE-/-:MMP-9+/+ plaques, whereas MMP-12 deficiency does not significantly affect lesion size or macrophage content. However, both MMP-9 and MMP12 deficiency protect against atherosclerotic media destruction and subsequent aneurysm formation [71].

A study in mice with combined deficiency of ApoE and TIMP-1 (ApoE-/-:TIMP-1-/-) showed that enhanced MMP activity, as a result of TIMP-1 deficiency, contributes to a reduction of plaque size but promotes aneurysm formation [72]. A similar study confirmed that the atherosclerotic lesions of ApoE-/-:TIMP-1-/- mice develop more aortic medial ruptures in which the elastic lamellae of the media are degraded and infiltrated with macrophages forming pseudo-microaneurysms [73]. Overexpression of TIMP-1 reduces atherosclerotic lesions in ApoE-/- mice [74] and prevents aortic aneurysm degeneration and rupture in a rat model [75], further substantiating a functional role of MMPs.

These studies implicate an important role of u-PA in the structural integrity of the atherosclerotic vessel wall, likely via triggering activation of MMPs, and suggest that increased u-PA levels are a risk factor for aneurysm formation [76].

\section{Pharmacological Modulation of MMP Activity}

Several studies have explored the potential of MMP inhibition in atherosclerosis. Avasimibe, an inhibitor of acyl-CoA: cholesterol 0-acyltransferase limits macrophage enrichment and thereby MMP expression resulting in stabilization of preestablished atherosclerotic lesions in rabbits [77]. Treatment of atherosclerotic cynomolgus monkeys with a broad spectrum MMP inhibitor after (stent)-angioplasty reveals inhibition of angiogenesis but no improve- 
ment of artery wall remodeling or intimal hyperplasia [78]. In a porcine model of atherosclerosis, antioxidant vitamins $\mathrm{C}$ and $\mathrm{E}$ contribute to stabilize atherosclerotic plaques after angioplasty by reducing vascular MMP-1 expression [79]. In patients requiring carotid endarterectomy, the non-specific MMP inhibitor doxycycline reduces the expression of MMP-1 in carotid plaques, whereas MMP-2, -3 , and -9 or TIMP-1 and -2 are not affected [80]. Thus, several lines of evidence support a role of MMP system components in development and progression of atherosclerosis, but a causative role is difficult to establish conclusively. The identification of specific proteinases involved in these processes and the development of more specific inhibitors will be required before presently available MMP inhibition can be a therapeutic option. The therapeutic potential of presently available MMP inhibitors has been reviewed [81-83]

\section{References}

1 Herity NA, Ward MR, Lo S, Yeung AC: Review: Clinical aspects of vascular remodeling. J Cardiovasc Electrophysiol 1999; 10: 1016-1024

2 Lijnen HR: Plasmin and matrix metalloproteinases in vascular remodeling. Thromb Haemost 2001; 86: 324-333.

3 Galis ZS, Khatri JJ: Matrix metalloproteinases in vascular remodeling and atherogenesis. The good, the bad and the ugly. Circ Res 2002; 90: 251-262.

4 Dickey RP, Hover JF: Ultrasonographic features of uterine blood flow during the first 16 weeks of pregnancy. Hum Reprod 1995; 10: 2448-2452. 5 Visse R, Nagase H: Matrix metalloproteinases and
tissue inhibitors of metalloproteinases. Structure, function and biochemistry. Circ Res 2003; 92: 827-839.

6 Somerville RPT, Oblander SA, Apte SS: Matrix metalloproteinases: old dogs with new tricks. Genome Biology 2003; 4: 216

7 Bode W, Gomis-Ruth FX, Stockler W: Astacins, serralysins, snake venom and matrix metalloproteinases exhibit identical zinc-binding environments (HEXXHXXGXXH and Met-turn) and topologies and should be grouped into a common family, the 'metzincins'. FEBS Lett 1993; 331: 134-140.

8 Massova I, Kotra LP, Fridman R, Mobashery S: Matrix metalloproteinases: structures, evolution, and diversification. FASEB J 1998; 12: 10751095.

9 Strongin AY, Collier I, Bannikov G, Marmer BL, Grant GA, Goldberg GI: Mechanism of cell surface activation of 72-kDa type IV collagenase. Isolation of the activated form of the membrane metalloprotease. J Biol Chem 1995; 270: 53315338.

10 Sato H, Seiki M: Membrane-type matrix metalloproteinases (MT-MMPs) in tumor metastasis. J Biochem (Tokyo) 1996; 119: 209-215.

11 Nagase H: Activation mechanisms of matrix metalloproteinases. Biol Chem 1997; 378: 151-160.

$\checkmark 12$ Brew K, Dinakarpandian D, Nagase H. Tissue inhibitors of metalloproteinases: evolution, structure and function. Biochim Biophys Acta 2000; 1477: 267-283.

13 Creemers EE, Cleutjens JP, Smits JF, Daemen MJ: Matrix metalloproteinase inhibition after myocardial infarction: a new approach to prevent heart failure? Circ Res 2001; 89: 201-210.

14 Sierevogel MJ, Pasterkamp G, de Kleijn DP, Strauss BH: Matrix metalloproteinases: a therapeutic target in cardiovascular disease. Curr Pharm Des 2003; 9: 1033-1040.

15 Kuzuya M, Iguchi A: Role of matrix metalloproteinases in vascular remodeling. $\mathrm{J}$ Atheroscler Thromb 2003; 10: 275-282.

Metalloproteinases in Vascular Disease
6 Jones CB, Sane DC, Herrington DM: Matrix metalloproteinases: a review of their structure and role in acute coronary syndrome. Cardiovasc Res 2003; 59: 812-823.

17 Ikeda U, Shimada K: Matrix metalloproteinases and coronary artery diseases. Clin Cardiol 2003; 26: 55-59.

18 Irizarry E, Newman KM, Gandhi RH, Nackman GB, Halpern V, Wishner S, Scholes JV, Tilson MD: Demonstration of interstitial collagenase in abdominal aortic aneurysm disease. J Surg Res 1993; 54: 571-574.

19 Newman KM, Jean Claude J, Li H, Scholes JV, Ogata Y, Nagase H, Tilson MD: Cellular localization of matrix metalloproteinase in the abdominal aortic aneurysm wall. J Vasc Surg 1994; 20: 814820.

20 Galis ZS, Sukhova GK, Kranzhöfer R, Clark S, Libby P: Macrophage foam cells from experimental atheroma constitutively produce matrixdegrading proteinases. Proc Natl Acad Sci USA 1995; 92: 402-406.

21 Halpert I, Sires UI, Roby JD, Potter-Perigo S, Wight TN, Shapiro SD, Welgus, HG, Wickline SA Parks WC: Matrilysin is expressed by lipid-laden macrophages at sites of potential rupture in atherosclerotic lesions and localizes to areas of versican deposition, a proteoglycan substrate for the enzyme. Proc Natl Acad Sci USA 1996; 93: 97489753.

22 Sakalihasan N, Delvenne P, Nusgens BV, Limet R, Lapiere CM: Activated forms of MMP2 and MMP9 in abdominal aortic aneurysms. J Vasc Surg 1996; 24: 127-133.

23 Moons L, Shi V, Ploplis V, Plow E, Haber E, Collen D, Carmeliet P: Reduced transplant arteriosclerosis in plasminogen deficient mice. J Clin Invest 1998; 102: 1788-1797.

24 Bendeck MP, Zempo N, Clowes AW, Galardy RE, Reidy MA: Smooth muscle cell migration and matrix metalloproteinase expression after arterial injury in the rat. Circ Res 1994; 75: 539-545.

25 Zempo N, Kenagy RD, Au YPT, Bendeck M, Clowes MM, Reidy MA, Clowes AW: Matrix metalloproteinases of vascular cells are increased in balloon-injured rat carotid artery. J Vasc Surg 1994; 20: 209-217.

26 Hasenstab D, Forough R, Clowes AW: Plasminogen activator inhibitor type 1 and tissue inhibitor of metalloproteinase- 2 increase after arterial injury in rats. Circ Res 1997; 80: 490-496.

27 Kenagy RD, Vergel S, Mattsson E., Bendeck M, Reidy MA, Clowes AW: The role of plasminogen, plasminogen activators, and matrix metalloproteinases in primate arterial smooth muscle cell migration. Arterioscler Thromb Vasc Biol 1996; 16: $1373-1382$.
28 Kenagy RD, Hart CE, Stetler-Stevenson WG, Clowes AW: Primate smooth muscle cell migration from aortic explants is mediated by endogenous platelet-derived growth factor and basic fibroblast growth factor acting through matrix metalloproteinases 2 and 9. Circulation 1997; 96: 3555-3560.

29 Aoyagi M, Yamamoto M, Azuma H, Nagashima G, Niimi Y, Tamaki M, Hirakawa K, Yamamoto K: Immunolocalization of matrix metalloproteinases in rabbit carotid arteries after balloon denudation. Histochem Cell Biol 1998; 109: 97-102.

30 Hojo Y, Ikeda U, Katsuki T, Mizuno O, Fujikawa $\mathrm{H}$, Shimada K: Matrix metalloproteinase expression in the coronary circulation induced by coronary angioplasty. Atherosclerosis 2002; 161: 185192.

31 Kalela A, Koivu TA, Sisto T, Kanervisto J, Hoyhtya M, Sillanaukee P, Lehtimaki T, Nikkari ST: Serum matrix metalloproteinase-9 concentration in angiographically assessed coronary artery disease. Scand J Clin Lab Invest 2002; 62: 337-

32 Lamblin N, Bauters C, Hermant X, Lablanche JM, Helbecque N, Amouyel P: Polymorphisms in the promoter regions of MMP-2, MMP-3, MMP-9 and MMP-12 genes as determinants of aneurysmal coronary artery disease. J Am Coll Cardiol 2002; 40: 43-48.

33 Blankenberg S, Rupprecht HJ, Poirier O, Bickel C, Smieja M, Hafner G, Meyer J, Cambien F, Tiret L, AtheroGene Investigators: Plasma concentrations and genetic variation of matrix metalloproteinase 9 and prognosis of patients with cardiovascular disease. Circulation 2003; 107: 1579-1585.

34 Carmeliet P, Moons L, Stassen JM, De Mol M, Bouché A, van den Oord JJ, Kockx M, Collen D: Vascular wound healing and neointima formation induced by perivascular electric injury in mice. Am J Pathol 1997; 150: 761-776.

35 Lijnen HR, Lupu F, Moons L, Carmeliet P, Goulding D, Collen D: Temporal and topographic matrix metalloproteinase expression after vascular injury in mice. Thromb Haemost 1999; 81: 799807.

36 Webb KE, Henney AM, Anglin S, Humphries SE, McEwan JR: Expression of matrix metalloproteinases and their inhibitor TIMP-1 in the rat carotid artery after balloon injury. Arterioscler Thromb Vasc Biol 1997; 17: 1837-1844.

37 Galis ZS, Johnson C, Godin D, Magid R, Shipley JM, Senior RM, Ivan E: Targeted disruption of the matrix metalloproteinase-9 gene impairs smooth muscle cell migration and geometrical arterial remodeling. Circ Res 2002; 91: 852-859. 
38 Cho A, Reidy MA: Matrix metalloproteinase-9 is necessary for the regulation of smooth muscle cell replication and migration after arterial injury. Circ Res 2002; 91: 845-851.

39 Kuzuya M, Kanda S, Sasaki T, Tamaya-Mori N, Cheng XW, Itoh T, Itohara S, Iguchi A: Deficiency of gelatinase A suppresses smooth muscle cell invasion and development of experimental intimal hyperplasia. Circulation 2003; 108: 1375-1381.

40 Lijnen HR, Van Hoef B, Vanlinthout I, Verstreken M, Rio M-C, Collen D: Accelerated neointima formation after vascular injury in mice with stromelysin-3 (MMP-11) gene inactivation. Arterioscler Thromb Vasc Biol 1999; 19: 28632870.

41 Lijnen HR, Van Hoef B, Soloway P, Collen D: Tissue inhibitor type 1 of matrix metalloproteinases (TIMP-1) impairs arterial neointima formation after vascular injury in mice. Circ Res 1999; 85 1186-1191.

42 Lovdahl C, Thyberg J, Cercek B, Blomgren K, Dimayuga P, Kallin B, Hultgardh-Nilsson A: Antisense oligonucleotides to stromelysin mRNA inhibit injury-induced proliferation of arterial smooth muscle cells. Histol Histopathol 1999; 14: 1101-1112.

43 Peterson M, Porter KE, Loftus IM, Thompson MM, London NJ: Marimastat inhibits neointimal thickening in a model of human arterial intimal hyperplasia. Eur J Vasc Endovasc Surg 2000; 19: 461-467.

44 de Smet BJ, de Kleijn D, Hanemaaijer R, Verheijen JH, Robertus L, van Der Helm YJ, Borst C, Post MJ: Metalloproteinase inhibition reduces constrictive arterial remodeling after balloon angioplasty: a study in the atherosclerotic Yucatan micropig. Circulation 2000; 101: 2962-2967.

45 Li C, Cantor WJ, Nili N, Robinson R, Fenkell L, Tran YL, Whittingham HA, Tsui W, Cheema AN, Sparkes JD, Pritzker K, Levy DE, Strauss BH: Arterial repair after stening and the effects of GM60001, a matrix metalloproteinase inhibitor. J Am Coll Cardiol 2002; 39: 1852-1858.

$\checkmark 46$ Zempo N, Koyama N, Kenagy RD, Lea HJ, Clowes AW: Regulation of vascular smooth muscle cell migration and proliferation in vitro and in injured rat arteries by a synthetic matrix metalloproteinase inhibitor. Arterioscler Thromb Vasc Biol 1996; 16: 28-33.

47 Forough R, Koyama N, Hasenstab D, Lea H, Clowes M, Nikkari ST, Clowes AW: Overexpression of tissue inhibitor of matrix metalloproteinase-1 inhibits vascular smooth muscle cell functions in vitro and in vivo. Circ Res 1996; 79: 812-820.

48 Furman C, Luo Z, Walsh K, Duverger N, Copin C, Fruchart JC, Rouis M: Systemic tissue inhibitor of metalloproteinase-1 gene delivery reduces neointimal hyperplasia in balloon-injured rat carotid artery. FEBS Lett 2002; 531: 122-126.

49 Turunen MP, Puhakka HL, Koponen JK, Hiltunen MO, Rutanen J, Leppanen O, Turunen AM Narvanen A, Newby AC, Baker AH, Yla-Herttuala S: Peptide-retargeted adenovirus encoding a tissue inhibitor of metalloproteinase-1 decreases restenosis after intravascular gene transfer. Mol Ther 2002; 6: 306-312.

50 George SJ, Johnson JL, Angelini GD, Newby AC, Baker AH: Adenovirus-mediated gene transfer of the human TIMP-1 gene inhibits smooth muscle cell migration and neointimal formation in human saphenous vein. Hum Gene Ther 1998; 9: 867877.
51 Lamfers MLM, Grimbergen JM, Aalders MC, Havenga MJ, de Vries MR, Huisman LGM, van Hinsbergh VWM, Quax PHA: Gene transfer of the urokinase-type plasminogen activator receptortargeted matrix metalloproteinase inhibitor TIMP1. ATF suppresses neointima formation more efficiently than tissue inhibitor of metalloproteinase1. Circ Res 2002; 91: 945-952.

52 Schneiderman J, Bordin GM, Engelberg I, Adar R, Seiffert D, Thinnes T, Bernstein EF, Dilley RB, Loskutoff DJ: Expression of fibrinolytic genes in atherosclerotic abdominal aortic aneurysm wall. A possible mechanism for aneurysm expansion. J Clin Invest 1995; 96: 639-645.

53 Lupu F, Heim DA, Bachmann F, Hurni M, Kakkar VV, Kruithof EK: Plasminogen activator expression in human atherosclerotic lesions. Arterioscler Thromb Vasc Biol 1995; 15: 1444-1455.

54 Henney AM, Wakeley PR, Davies MJ, Foster K, Hembry R, Murphy G, Humphries S: Localization of stromelysin gene expression in atherosclerotic plaques by in situ hybridization. Proc Natl Acad Sci USA 1991; 88: 8154-8158.

55 Galis SZ, Muszynski M, Sukhova GK, SimonMorrisey E, Libby P: Enhanced expression of vascular matrix metalloproteinases induced in vitro by cytokines and in regions of human atherosclerotic lesions. Ann NY Acad Sci 1995; 748: 501507.

56 Schonbeck J, Mach F, Sukhova GK, Atkinson E, Levesque E, Herman M, Graber P, Basset P, Libby $\mathrm{P}$ : Expression of stromelysin-3 in atherosclerotic lesions: regulation via CD40-CD40 ligand signaling in vitro and in vivo. J Exp Med 1999; 189: 843-853.

57 Rajavashisth TB, Xu XP, Jovinge S, Meisel S, Xu XO, Chai NN, Fischbein MC, Kaul S, Cercek B, Sharifi B, Shah PK: Membrane type 1 matrix metalloproteinase expression in human atherosclerotic plaques: evidence for activation by proinflammatory mediators. Circulation 1999; 99: 31033109.

58 Hong BK, Kwon HM, Lee BK, Kim D, Kim IJ, Kang SM, Jang Y, Cho SH, Kim HK, Jang BC, Cho SY, Kim HS, Kim MS, Kwon HC, Lee N: Coexpression of cycloxygenase- 2 and matrix metalloproteinases in human aortic atherosclerotic lesions. Yonsei Med J 2000; 41: 82-88.

59 Uzui H, Harpf A, Liu M, Doherty TM, Shukla A, Chai NN, Tripathi PV, Jovinge S, Wilkin DJ, Asotra K, Shah PK, Rajavashisth TB: Increased expression of membrane type 3-matrix metalloproteinase in human atherosclerotic plaque: role of activated macrophages and inflammatory cytokines. Circulation 2002; 106: 3024-3030.

60 Xu XP, Meisel SR, Ong JM, Kaul S, Cercek B, Rajavashisth TB, Sharifi B, Shah PK: Oxidized low-density lipoprotein regulates matrix metalloproteinase- 9 and its tissue inhibitor in human monocyte-derived macrophages. Circulation 1999; 99: 993-998.

61 Moreau M, Brocheriou I, Petit L, Ninio E, Chapman MJ, Rouis M: Interleukin-8 mediates downregulation of tissue inhibitor of metalloproteinase-1 expression in cholesterol-loaded human macrophages: relevance to stability of atherosclerotic plaque. Circulation 1999; 99: 420-426.

62 Fabunmi RP, Sukhova GK, Sugiyama S, Libby P: Expression of tissue inhibitor of metalloproteinases-3 in human atheroma and regulation in lesionassociated cells: a potential protective mechanism in plaque stability. Circ Res 1998; 83: 270-278.
63 Orbe J, Fernandez L, Rodriguez JA, Rabago G, Belzunce M, Monasterio A, Roncal C, Paramo JA: Different expression of MMPs/TIMP-1 in human atherosclerotic lesions. Relation to plaque features and vascular bed. Atherosclerosis 2003; 170: 269276.

64 Saito S, Zempo N, Yamashita A, Takenaka H, Fujioka K, Esato K: Matrix metalloproteinase expressions in arteriosclerotic aneurysmal disease. Vasc Endovascular Surg 2002; 36: 1-7.

65 Beaudeux JL, Giral P, Bruckert E, Bernard M, Foglietti MJ, Chapman MJ: Serum matrix metalloproteinase-3 and tissue inhibitor of metalloproteinases- 1 as potential markers of carotid atherosclerosis in infraclinical hyperlipidemia. Atherosclerosis 2003; 169: 139-146.

66 Ferroni P, Basili S, Martini F, Cardarello CM, Ceci F, Di Franco M, Bertazzoni G, Gazzaniga PP, Alessandri C: Serum metalloproteinase 9 levels in patients with coronary artery disease: a novel marker of inflammation. J Investig Med 2003; 51: 295-300.

67 Jormsjo S, Wuttge DM, Sirsjo A, Whatling C, Hamsten A, Stemme S, Eriksson P: Differential expression of cysteine and aspartic proteases during progression of atherosclerosis in apolipoprotein E-deficient mice. Am J Pathol 2002; 161: 939945.

68 Dollery CM, Owen CA, Sukhova GK, Krettek A, Shapiro SD, Libby P: Neutrophil elastase in human atherosclerotic plaques: production by macrophages. Circulation 2003; 107: 2829-2836.

69 Shi W, Brown MD, Wang X, Wong J, Kallmes DF, Matsumoto AH, Helm GA, Drake TA, Lusis AJ: Genetic backgrounds but not sizes of atherosclerotic lesions determine medial destruction in the aortic root of apolipoprotein E-deficient mice. Arterioscler Thromb Vasc Biol 2003; 23: 19011906.

70 Silence J, Lupu F, Collen D, Lijnen HR: Persistence of atherosclerotic plaque but reduced aneurysm formation in mice with stromelysin-1 (MMP-3) gene inactivation. Arterioscler Thromb Vasc Biol 2001; 21: 1140-1145.

71 Luttun A, Lutgens E, Manderveld A, Maris K, Collen D, Carmeliet P, Moons L: Loss of matrix metalloproteinase-9 or matrix metalloproteinase12 protects apolipoprotein E-deficient mice against atherosclerotic media destruction but differentially affects plaque growth. Circulation 2004; 109: 1408-1414.

72 Silence J, Collen D, Lijnen HR: Reduced atherosclerotic plaque but enhanced aneurysm formation in mice with inactivation of the tissue inhibitor of metalloproteinase-1 (TIMP-1) gene. Circ Res 2002; 90: 897-903.

73 Lemaitre V, Soloway PD, D'Armiento J: Increased medial degradation with pseudo-aneurysm formation in apolipoprotein E-knockout mice deficient in tissue inhibitor of metalloproteinases-1. Circulation 2003; 107: 333-338.

74 Rouis M, Adamy C, Duverger N, Lesnik P, Horellou P, Moreau M, Emmanuel F, Caillaud JM, Laplaud PM, Dachet C, Chapman MJ: Adenovirus-mediated overexpression of tissue inhibitor of metalloproteinase- 1 reduces atherosclerotic lesions in apolipoprotein E-deficient mice. Circulation 1999; 100: 533-540.

75 Allaire E, Forough R, Clowes M, Starcher B, Clowes AW: Local overexpression of TIMP-1 prevents aortic aneurysm degeneration and rupture in a rat model. J Clin Invest 1998; 102: 1413-1420. 
76 Carmeliet P, Moons L, Lijnen HR, Baes M, Lemaitre V, Tipping P, Drew A, Eeckhout Y, Shapiro S, Lupu F, Collen D: Urokinase-generated plasmin activates matrix metalloproteinases during aneurysm formation. Nat Genet 1997; 17: 439444.

77 Bocan TM, Krause BR, Rosebury WS, Mueller SB, Lu X, Dagle C, et al: The ACAT inhibitor avasimibe reduces macrophages and matrix metalloproteinase expression in atherosclerotic lesions of hypercholesterolemic rabbits. Arterioscler Thromb Vasc Biol 2000; 20: 70-79.
78 Cherr GS, Motew SJ, Travis JA, Fingerle J, Fisher L, Brandl M, et al: Metalloproteinase inhibition and the response to angioplasty and stenting in atherosclerotic primates. Arterioscler Thromb Vasc Biol 2002; 22: 161-166.

79 Orbe J, Rodriguez JA, Arias R, Belzunce M, Nespereira B, Perez-Ilzarbe M, Roncal C, Paramo JA: Antioxidant vitamins increase the collagen content and reduce MMP-1 in a porcine model of atherosclerosis: implications for plaque stablization. Atherosclerosis 2003; 167: 45-53.

80 Axisa B, Loftus IM, Naylor AR, Goodall S, Jones L, Bell PR, Thompson MM: Prospective, randomized, double-blind trial investigating the effect of doxycycline on matrix metalloproteinase expression within atherosclerotic carotid plaques. Stroke 2002; 33: 2858-2864.
81 George SJ: Therapeutic potential of matrix metalloproteinase inhibitors in atherosclerosis. Exp Opin Invest Drugs 2000; 9: 993-1007.

82 Watanabe N, Ikeda U: Matrix metalloproteinases and atherosclerosis. Curr Atheroscler Rep 2004; 6 : 112-120.

83. Beaudeux JL, Giral P, Bruckert E, Foglietti MJ, Chapman MJ: Matrix metalloproteinases, inflammation and atherosclerosis: therapeutic perspectives. Clin Chem Lab Med 2004; 42: 121-131. 